\title{
Shelf Projects: The Political Life of Exploration Geology in Senegal
}

\author{
ROBYN d'AVIGNON \\ NEW YORK UNIVERSITY
}

\begin{abstract}
Since the early 2000s, southeastern Senegal has emerged as a premier gold exploration and mining frontier. At present, the Sabodala gold mine, owned by the Canadian company Teranga Gold, is the only operational gold mine and mill in Senegal. But two more open-pit gold operations are scheduled to open this year, and several other companies have announced discoveries of industrial-scale deposits. By documenting the shifting ownership and exploration of the Sabodala deposit, this article draws attention to how the protracted phase of mineral research shapes the political life of mining operations in Africa and elsewhere in the global South. Geological exploration in colonial and post-colonial Senegal, as in much of Africa, has relied heavily on the expertise of indigenous miners and smelters. Mining Sabodala has thus unearthed multi-vocal and contested histories of gold discovery. Historians of science have established that field assistants and experts in Africa have produced agronomic and medical knowledge typically credited to "the West." By extending this argument to gold exploration, the article brings African history into dialogue with an emergent anthropology of subterranean knowledge production.
\end{abstract}

\section{Keywords}

exploration geology; shelf projects; Senegal; discovery; conflict

\section{Introduction}

I first met Dembélé Danfakha in April 2013 while conducting research on the history of gold exploration in Senegal. ${ }^{2}$ Danfakha's name emerged repeatedly in oral histories with residents of the region of Kédouogu, the heart of Senegal's gold mining industry. Now in his late 70s, Danfakha has guided dozens of exploration geologists and gold prospectors from Paris, St. Petersburg, Toronto, Melbourne, and the Senegalese capital of Dakar into the rugged savannah of southeastern Senegal. I was the most recent visitor seeking his expertise in metals. Danfakha lives in Mamakhono, a Maninka village of several thousand located 35 kilometers from Senegal's

'Robyn d'Avignon, Email: robyn.davignon@nyu.edu 2I have changed the names of my interlocutors to protect their identity.

Copyright (C) 2018 (Robyn d'Avignon). Licensed under the Creative Commons Attribution Non-commercial No Derivatives (by-nc-nd). Available at estsjournal.org. 


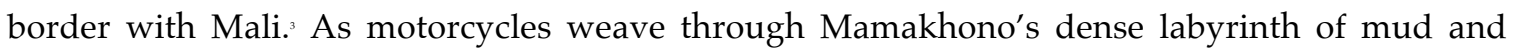
thatch huts, they churn up a rust red dust produced by the oxidization of iron rich soils. Most of Senegal is flat, covered in young sedimentary deposits. Kédougou, by contrast, is marked by uneven terrain, jagged outcrops, and blackened volcanic rock. The region occupies the eastern half of the Kédougou-Kenieba Inlier, situated within the West African Birimian Greenstone Belt. This geological formation distributes copper, gold, uranium, and iron across portions of eastern Senegal, Mali, Guinea, Burkina Faso, Ghana, Cote d'Ivoire, and Niger. Danfakha descends from a family of multi-generational gold miners, referred to today as "artisanal" miners or orpailleurs in French. He rises as I approach the doorway of his modest concrete home. We greet each other in a mixture of French and Maninkakan, until he points abruptly to the west. Just out of view is the Sabodala gold mine, owned by the Canadian company Teranga Gold. "The first thing you need to know," Danfakha begins, "they did not discover Sabodala." He gestures to his chest: "We did."

Danfakha's declaration is part of a growing suite of historical claims made by West Africans living in auriferous zones where private mining corporations are opening industrialscale gold mines. Since the early 2000s, Kédougou has become-in the parlance of the global mining industry—an "emergent," "under-explored," and "world-class gold belt" (CNBC 2015). As of this writing, Sabodala is the only commercial gold mine and mill in Kédougou, but the state has approved exploitation permits for Bassari Resources and Toro Gold Ltd. to develop truck and shovel open-pit gold mines. IAMGOLD Corporation and Randgold Resources have also documented gold reserves within the region, and announced their intention to convert these discoveries into future mines. Just across the border in Mali, now the third largest producer of gold in Africa, sit the mining operations of Yatela and Sadiola (Anglogold/IAMGOLD); Loulo and Gounkoto (Randgold); and Fekola (B2Gold). Many of Mamakhono's residents work as drivers, day laborers, and cleaners for the Sabodala mine and for other exploration companies operating in the region. But most men and women labor as orpailleurs, mining gold with locally forged handpicks, mortar-pickers, and dynamite. Orpaillage has been conducted in Kédougou for hundreds, potentially thousands, of years. This region formerly occupied the western edge of Bambuk, a pre-colonial gold-producing province that furnished gold to the Mediterranean world via the trans-Saharan trade from roughly $400 \mathrm{CE}$ through much of the $16^{\text {m }}$ century. Historically a dry-season complement to rain-fed agriculture, many residents now mine for gold year-round. Today, orpaillage is the primary source of non-farm cash income in Kédougou (Persaud et al. 2017). The Senegalese state has used different legal and extralegal mechanisms to manage orpaillage: forcefully expelling artisanal miners from deposits slated for corporate exploitation, creating permits for Senegalese citizens to authorize orpaillage in state-drawn "corridors"; and leaving mining companies to arrange informal co-habitation agreements with orpailleurs. Stateissued exploration permits, most of which are held by expatriate firms, now cover the majority of Kédougou's $10,400 \mathrm{~km}^{2}$ surface area. Conflicts between orpailleurs and private exploration firms

${ }^{3}$ Manding refers to the language-dialect continuum in West Africa that stretches from Senegal to Burkina Faso. Maninka denotes speakers of Maninkakan, a Manding dialect spoken in eastern Senegal. 
have intensified in recent years. This trend is documented across West Africa (Hilson and Yakovleva 2007; Luning 2014; Luning and Pijpers 2017; Okoh 2014). Increasingly, regional residents justify mining for gold within exploration permits on the grounds that theyorpailleurs - were the first to discover many gold deposits now of interest to corporate capital.

Danfakha's declaration evidences that competing knowledge claims about the underground-and not simply material interests-animate the politics of mining and private capital investment in Africa (see Ferry and Limbert 2008; Goldman and Turner 2010; Pritchard 2003). Scholars of science and technology studies (STS) have long argued that knowledge does not confer power in any direct correspondence. But the search for knowledge does have important material effects. For example, historians and geographers document that states have long used map-making technologies to exercise representational and instrumental power over resources, land, and people (for an overview of STS debates on mapmaking, see Rankin 2016; see also Winichakul 1994; Wood and Fels 2008). The literature on cartography in Africa emphasizes how imperial powers and post-colonial states used maps to rationalize landscapes for the purposes of taxation and conscription, to segregate European settlers from indigenous Africans, and to fix pastoralists and mobile agriculturalists into place-bound "ethnic groups" (Gray 2002; Scott 1998; MacArthur 2016:15-23). In a recent monograph on mapmaking in northern Kenya, Julie MacArthur challenges the proposition that maps are a state-based imposition on local understandings of geography and social groupings. Rather, she argues, African ethnic and political entrepreneurs embraced cartography as a tool for giving their political agendas a "geographic character" (MacArthur 2016:17, 19-20).

While historians of Africa continue to explore the production of 2-dimensional geographic space by states, corporations, and ethno-linguistic groups, there is little attention to how maps and models of the underground produce claims on territories and populations. Geographers have called for studies of the production of "volumetric" or 3-dimensional space; in particular, the techniques used to render the air and the underground visible, governable, and marketable (Bridge 2009; Elden 2013). As Bruce Braun (2000) argues, beginning in the 18 century, the developing science of geology and mineral mapping gave the territory of the state-and colonial empires-a vertical dimension (see also Westermann 2015). Ethnographies of exploration geology in Canada, Ecuador, and Principe and Sao Tome document the discursive techniques (Kneas 2016; Ozden-Schilling, m.s.) and physical "gestures" (Weszkalnys 2015) used by exploration companies to communicate the potential value of the underground to investors. Drawing on insights from literature on the performativity of markets and the sciences of calculability (Mackenzie 2009; Mackenzie et al., 2012; Monika, Goodwin, and Mesman 2010), these studies reveal that minerals do not exist, a priori, as valuable commodities. Rather, mineral resources are brought into being through abstraction, modeling, market devices, infrastructures, and laws (Ferry and Limbert 2008:4; Kaup 2008; Richardson and Weszkalnys 2014).

I draw inspiration from this emergent ethnography of geological practice to unpack a more historical case: the contentious discovery and shifting ownership of Sabodala (See Figure 1)—once a mountain, now a gaping open-pit gold mine in the region of Kédougou. The process that enabled this rock formation to become legible as a world-class gold deposit was collaborative 
and contentious. There was no single moment in which Sabodala was discovered. Rather, the value of this deposit was modified by exploration activities conducted by orpailleurs and geologists; modifications to Senegal's mining laws; shifting global market prices for gold; and new exploration and mining technologies. Sabodala, similar to many gold deposits mined by private companies in Africa today, is not a new discovery. State-sponsored and private mineral missions first officially documented the deposit in the 1960s and 1970s. But it was the presence of orpailleurs that attracted geologists to Sabodala in the first place. Over decades, Senegalese and expatriate earth scientists, orpailleurs, corporations, and government officials transformed the volcanic rock of Sabodala into an evidenced gold reserve that the Senegalese state could market to private bidders. If local populations first mined alluvial deposits associated with the deposit, professional geologists deepened knowledge of the underlying ore body and its broader geological context through trenching, drilling, and geochemical and geophysical studies. Teranga's knowledge acquisition is ongoing as it exploits deposits adjacent to Sabodala and conducts exploration geology on $1000 \mathrm{~km}^{2}$ of combined exploration permits (Teranga 2018).

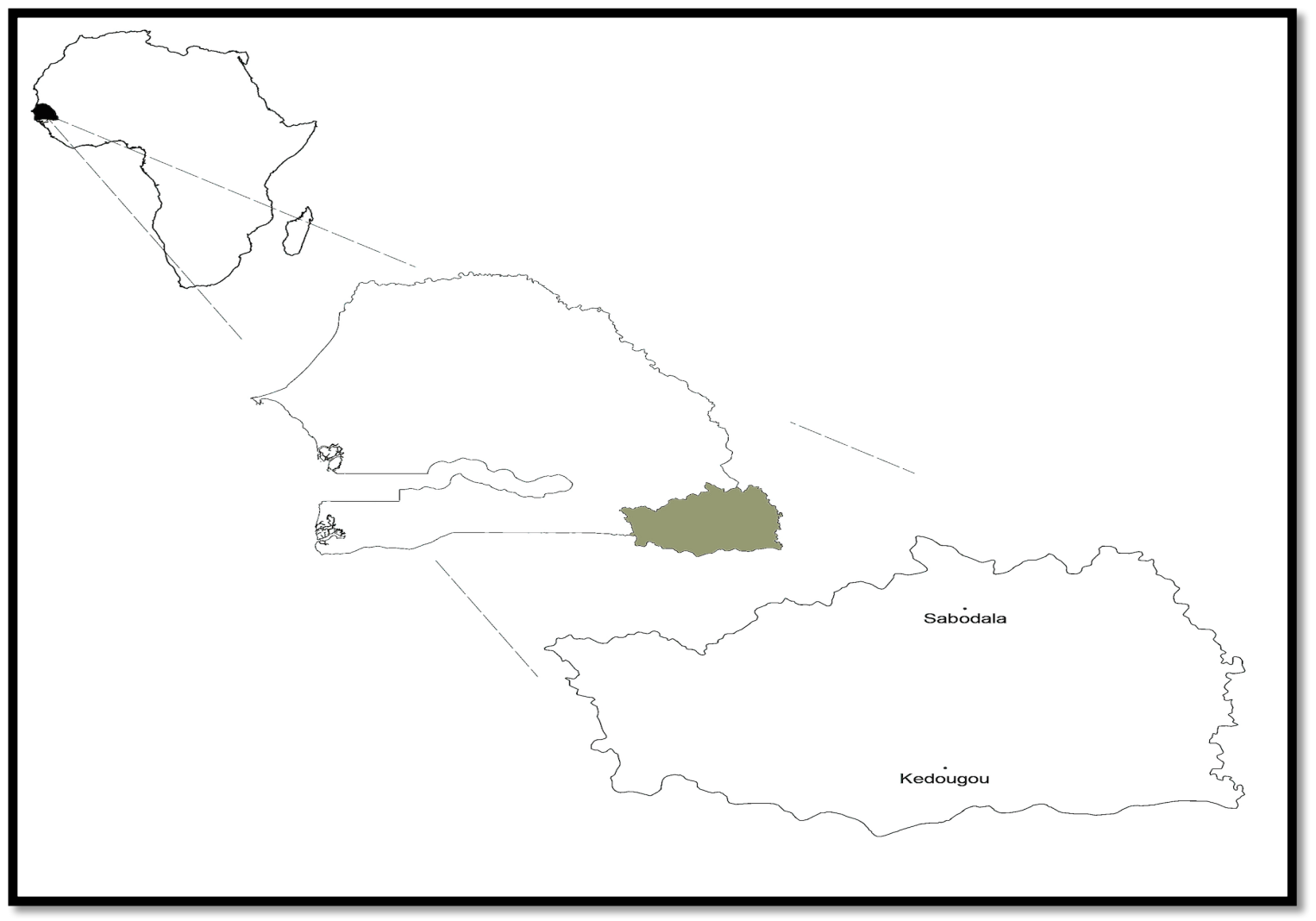

Figure 1. Map of the region of Kedougou in the Republic of Senegal, indicating Sabodala gold mine and Kedougou town. Map designed by Stephen Wood. 
The case of Sabodala advances two contributions to a science and technology studies of the underground-an inquiry concerned with the forms of expertise and material practices involved in transforming the subsurface into a platform for social, political, and economic action. For one, attention to the history of mineral exploration shifts the temporal focus of mining literature. The scholarship on mining in Africa is a rich one. Early studies of colonial capitalintensive mining on the Central African Copperbelt and in the gold and diamond mines of South Africa produced some of the earliest reflections on urbanization, wage labor relations, and ethnic consciousness in Africa (Crush, Jeeves and Yudelman 1991; Gluckman 1961; Powdermaker 1962; Van Onselen, 1976). Similar to anthropological research on mining in Latin America (Nash 1993; Taussig 1980) these studies addressed questions about labor, capitalism, and class and ethnic identity. In the 1990s, global mining capital began to operate increasingly in the Global South and on indigenous lands. Scholars of mining began to examine the social effects of corporate social responsibility programs (Rajak 2011; Welker 2014); relations between mining companies, indigenous communities, and non-governmental organizations (Kirsch 2006, 2014; Sawyer 2004); and the new political geographies of "off-shore" oil drilling (Appel 2012; Ferguson 2006).

Despite this widening breadth of topics, mining scholarship has remained focused on the extractive process or on the social life of decline "after the rush" (Ferguson 1999; Walsh 2012). Yet, in most of the world, exploration activities are far more ubiquitous than mining itself. Geologists spend years conducting exploration before a mine is opened. Compared to extraction, exploration is also relatively unregulated. Operating on modest budgets and in shoestring "bush camps," venture-capital funded "junior" exploration teams often forge intimate relationships with local residents, including artisanal miners. Some gold exploration teams employ more local labor than extractive firms, which supplant labor with high-tech machinery. This article joins a small, but growing, literature interested in how the protracted phase of exploration geology shapes the politics and economics of mining (Luning 2014; Luning and Pijpers 2017; Weszkalnys 2015).

The second goal of this article is to bring perspectives from African history into conversation with a critical literature on the mapping and modeling of the underground. I argue that exploration for hard metals in Africa today, and in the more distant past, has relied heavily on indigenous mining activities. Historians of science in Africa have established that the development of the field sciences of agronomy (Tilley 2010), botany (Osseo-Asare 2014), topography (MacArthur 2016) and ornithology (Jacobs 2016) relied intensively on African field assistants, healers, blacksmiths, and hunters. Because funding for scientific research in colonial Africa was sparse, collaboration with African experts was central to the production of knowledge about Africa (Tilley 2010). In a study of plant-based pharmaceuticals in Africa, Abena Dove Osseo-Asare (2014) argues that healers, scientists, elderly women, corporations, and communities shaped the production of medical knowledge about plants and their healing properties. She contrasts the "fragmented, synchronous stories of shared creation" of plant knowledge with narratives of "priority" that insist with certitude that "we know the time of each discovery" and omit the contributions of less powerful actors (110). Studies of bioprospecting underscore the difficulty of assigning benefit to the multiple protagonists-including national scientists, 
merchants, and rural healers-involved in scientific discovery (Hayden 2003; Schiebinger 2007).

The parallels with mineral discovery are remarkable. Since colonial conquest in the late nineteenth century, and earlier in some regions, Europeans relied heavily on African gold, copper, and iron workings and smelting sites to generate projections about mineralization and regional geological formations (d'Avignon 2016, esp. chap. 3)." Many European mining industries established in colonial Africa were "take-overs" of African mines, followed by an investment in capital, machinery, and further geological exploration. This was the case for the copper and gold mining industries of Southern Africa (Summers 1969; Van Onselen 1976); gold mining in late nineteenth century Ghana (Dumett 1998), and British tin mining on the Jos Plateau of Nigeria (Freund 1981). Similar to the search for healing plants in Africa, the contributions of geologists, artisanal miners, smelters, and prospectors to locating tin, gold, and copper deposits complicates the question of who should benefit from mining these deposits. As revealed by the Sabodala case, mining unearths these contested histories of collaborative discovery and uneven benefit.

Our story of Sabodala begins and ends from the vantage point of Dembélé Danfakha's household, which today sits within Teranga Gold's Sabodala mining concession. From Mamakhono, I first survey the competitive stories surrounding the discovery, promotion, and extraction of Sabodala. I then examine how these claims have become animated in debates concerning who has a right to mine Sabodala and adjacent gold deposits. This article draws on a corpus of interviews and archival materials I assembled in Senegal, Guinea and France between 2010 and 2015. During this time I carried out fifteen months of ethnographic research in the town of Kédougou and in a cluster of villages that participate in orpaillage. In Senegal I conducted over two hundred formal oral history interviews with geologists, government officials, orpailleurs, healers, ritual specialists, elders, journalists, NGO workers, mining camp managers, and local historians. I also carried out ethnographic research in gold exploration camps and conducted interviews in Dakar and France. The questions driving this research-and the social networks that sustain it-emerge from my engagement with families and villages in Kédougou that began when I first lived in the region as a Peace Corps volunteer from 2006 to 2008.

\section{Who discovered Sabodala?}

In 1960, Senegal gained independence from France in a peaceful transfer of power. Leopold Sedar Senghor became the country's first president. Senegal retained close diplomatic and financial ties with France, but Senghor actively dismantled many colonial institutions and worked to diversify Senegal's economy beyond its historic reliance on peanut exports. Senghor's government was concerned with creating new economic opportunities in peripheral regions that had been largely ignored by the French colonial state, treated as seasonal labor reserves for Dakar and peanut farms located in Senegal's central-west basin. At independence, Kédougou was a poor, isolated, and sparsely populated department within the region of Senegal Orientale. Senghor hoped to

4 This argument only holds for metals historically mined by peoples in Africa, such as copper, gold, tin, and iron. Exploration for petroleum, which was not constitutive of pre-colonial economies and culture, entails a different set of engagements with local labor, expertise, and heritage (e.g., Appel 2012; Weszkalnys 2015). 
transform Kédougou into a regional economic pole by developing the region's unique endowments of iron and gold into state owned and operated mining industries.

Senghor's administration was well aware of the antiquity of southeastern Senegal's mining economy. It was in search of the fabled goldfields of Bambuk-which aligns with the Kédougou-Kenieba Inlier geological belt-that Portuguese ships first traveled down the West African coast in the fifteenth century. The French would come to dominate trade along the Senegal River, and the focus of their commerce was human slaves. Yet French travelers and merchants never stopped speculating about the possibility of controlling indigenous gold production or trade (Curtin 1973). Between the 1860s and the 1890s, the French military violently seized Bambuk and other gold-producing territories in Guinea, Soudan (now Mali), and Haute Volta (now Burkina Faso) from West African military leaders. However, early attempts by private French firms to mine gold in what became the federation of Afrique Occidentale Francaise largely failed. Until the late 1950s, the federation's primary mineral export was gold mined by African orpailleurs.

During the colonial period, only a single European mining firm operated in Kédougou. Established in 1911, the "Compagnie des Mines de Falémé-Gambie" ran three boat dredges on the Falémé River that agitated and filtered gold dust from riverbed silts. In most years, gold purchased from African miners constituted the bulk of the firm's reported "production." After World War II, the Service of Geology received fresh funds from the newly reconfigured French Union for mineral exploration in West Africa. Among several projects, the Service prioritized the exploration of gold, iron, and diamonds in southeastern Senegal. In the 1950s, French geologists commissioned by the Mining Bureau of Overseas France to research the structural geology of the region, produced detailed maps of active and abandoned orpaillage sites (Bassot 1961).

During the 1960s, and in the context of the global Cold War, Senegalese officials set out to expand upon colonial-era mineral studies in Senegal Orientale. They did so by brokering aid partnerships with France, the Soviet Union, and the United Nations Development Organization (UNO). Senegal was an early recipient of multi-lateral development aid from the UNO, which supported the organization's goal of building national scientific expertise in post-colonial states. At the same time, powerful members of the UNO-Russia, the United States, and Canada-were interested in surveying mineral deposits to respond to growing global concerns about population growth and the depletion of mineral reserves in heavily industrialized countries (Dixey 1961). From 1963 to 1971, the UNO funded three mineral missions to Senegal: a general "Mineral Survey of Senegal Oriental" and two subsequent missions focused on gold and copper. The UNO identified sizable copper and iron deposits, but determined they could not be profitably exploited with current market prices. The UNO also explored for gold near Mamakhono and Sabodala, following up on some soil sampling, pitting, and trenching of orpailleur gold workings in the area conducted in 1961 by a French parastatal called the Bureau de Recherche Géologique et Minière (BRGM). The UNO sampled promising gold quartz veins near Mamakhono and Sabodala, and they advised the Senegalese state to conduct further gold prospecting in the zone. For this task,

${ }^{5}$ Archives Nationale du Sénégal, Documentation, “Operation Kédougou," February 29—March 4, 1960. 
Senegal created a bi-lateral aid partnership with the USSR, the longest of its kind carried out on Senegalese soil. Referred to as "Sénégalo-Sovietique," Russian geologists carried out trenching, diamond drilling, and geochemical testing of quartz vein style and alluvial gold mineralization on Sabodala. After the mission concluded in 1973, BRGM continued exploration of the deposit, updating the estimated reserves of Sabodala to 17 tons of gold by the early 1980s.

In official documents and memory, the discovery of Sabodala by the combined research of BRGM and Sénégalo-Sovietique was considered the most important, cumulative achievement of the state's multi-decade effort to recruit foreign experts to map the mineral reserves of Senegal Orientale. Also evident from the reports produced by these mineral missions is that orpailleurs played a considerable role in these exploration endeavors. In fact, much of the trenching and diamond drilling carried out in the 1960s-70s was guided by orpailleur workings. In a massive region, where gold is distributed widely across a poorly understood geological formation, the primary index for expatriate geologists were deposits already mined by local populations. For over a dozen years, the village of Mamakhono hosted rotating teams of expatriate geologists during the Sahelian dry-season. UNO, BRGM, and Sénégalo-Sovietique employed men from Mamakhono and nearby villages to work as bush guides, trail cutters, and to dig exploration trenches. Orpailleurs guided French, Soviet, and Swiss geologists to local diouras - the Maninka term for gold mine. Because gold prices were at historic lows in the 1960s, most diouras were inactive. Geologists working for these mineral missions actively recruited the descendants of Maninka mining families, including Danfakha. While Sabodala was the most important discovery of the independence-era mineral missions, geologists dug exploration trenches into dozens of other diouras and mapped their locations. Today, some of these discoveries are slated to become open-pit mines operated by private firms based in South Africa, Canada, and Australia.

Dembélé Danfakha, and other men and women of his generation, locate the history of gold exploration in southeastern Senegal in a much deeper genealogy. Mamakhono and Sabodala were part of the pre-colonial province of Bélédougou, founded by successive waves of Maninka migrants beginning in the $13^{\text {in }}$ century. According to oral histories collected in the zone, Bélédougou's settlers migrated from the Manding speaking empire of Mali, which rose to power between the $13^{\text {th }}$ and $15^{\text {m }}$ century and, at its height, encompassed much of modern-day Guinea and Mali. Migrants were attracted to Bélédougou's fertile agricultural soils, but skilled Maninka blacksmiths also selected the zone due to the marked presence of gold and iron in the surrounding hillsides. Mamakhono, one of the oldest villages in Bélédougou, was fortified and home to a coordinated military that defended against slave raids during the height of the transAtlantic slave trade in the $17^{\text {i }}$ and $18^{\text {m }}$ centuries (see also Diallo 2006: 26-28). The village of Sabodala, by contrast, was initially established as a dioura, mined during the dry season by residents of Mamakhono and other historic villages of Bélédougou. Sabodala eventually became a site of permanent, year-round residence. The historical conversion from dioura to village (dugu) is a common pattern of settlement in Kédougou. Indeed, oral historical and archeological

'Author's Interview, Dec 12, 2013; Author's Interview, April 2, 2014.

- Author's Interview, June 6, 2014; Author's Interview, June 4, 2014. 
evidence suggests that Maninka expansion westward and southward from 1300-1900 CE was driven in part by the search for new gold and iron deposits (Gokee 2016; Wilks 1971).

Men and women in Bélédougou engaged in gold mining during the dry season, from November to April. For centuries, gold mining in Sabodala and adjacent areas was focused on alluvial gold-metal disaggregated from "parent-rock" through geological weathering processes and carried through the local water table. Women panned for gold along the Falémé River and its tributaries, teaching their daughters to scoop the murky silts of rivers with weighted gourds. Men instructed their sons and grandsons to scan the savannah landscape for indexes of underlying gold: the presence of trees associated with ferruginous or auriferous soils, clusters of shrubs indicating an ancient waterway located underfoot. Children of Bélédougou learned to taste and smell the soil for gold, which in some soils was nearly invisible to the human eye. Both men and women consulted local diviners and guardians of family shrines for assistance in prospecting for gold. An elected "chief of the mines" (diourakuntigi) performed blood sacrifices to appease the land spirits who guarded gold and other metals underground. Ritual and practical knowledge comprised an integrated repertoire of techniques to transform heterogeneous landscapes of rocks, silt, quartz, and mineral veins into fertile diouras (d'Avignon 2016, chap. 1).

In the 1960s, Danfakha was proud to share the location of historic diouras with geologists. Danfakha wanted to take part in Senegal's national development and aspired to future employment in a modern, state-owned, industrial mine. During the 1960s and early 1970s, the price of gold was at a record low and families only mined occasionally during the height of the dry season. There were few signs that this reserve-which residents tapped into seasonally and at times of severe drought and famine-was under threat of expropriation.

\section{Shelf Projects}

In the 1970s, mineral prices, with the exception of oil, plunged to historic lows. Grossly underfunded, Senegal's Direction of Mines and Geology (DMG) took on a largely administrative role, operating as a gatekeeper for the occasional permit requests of French parastatal mining companies. Located far from Dakar's port and a robust energy infrastructure, Sabodala became a "shelf project." The extensive research documenting the reserve was literally archived on the shelves of the DMG." By the 1980s, prices for peanuts, still Senegal's primary export, plummeted and the national economy was suffering. Droughts of the late 1970s and early 1980s took a massive toll on agriculture and human health across the Sahel, hitting eastern Senegal particularly hard. With mounting debt to international lending agencies, the World Bank and the International Monetary Fund offered African states debt forgiveness in exchange for adopting "structural adjustment reforms" (SAPS) and cutting government spending on bureaucracy, education, health, and agricultural subsidies. Senegal was an early adopter of SAPS, but after

: In the 1960s and 1970s, phosphate mining in the region of Thiès and Dakar, located less than 100 kilometers from Dakar's deep-sea port, was Senegal's sole mining industry. 
fifteen years of budget cuts and currency re-evaluations, the state was still saddled by foreign debt and deficits.

In the deteriorating economic context of the 1980s, the DMG began to promote Senegal's shelf projects to private investors. Senegal adopted a more "investor-friendly" mining code in 1988, following the broader trend of privatization in Africa's mining sector. In the mid-1980s, the state-owned "Societe Miniere de Sabodala" (SMS) signed a joint venture agreement with BRGM to exploit Sabodala. After an unfavorable pre-feasibility study in 1998, BRGM retreated from the project. In 1992, SMS entered discussions with a junior Australian company, Paget, to mine Sabodala. Paget constructed an airstrip and an exploration camp at the site, and completed more reverse circulation and diamond drilling. The partnership was renounced, however, in 1994. In the same year, Senegal's second president, Abdou Diouf, convened a special inter-ministerial council to discuss the promotion of Sabodala. SMS decided to develop the Sabodala project with a Senegalese company by the name of La Société d'Etudes et d'Exploitation Industrielles Minières et Commerciales de l'Or (Eeximcor). Composed exclusively of Senegalese technicians and laborers, Eeximcor was unique in Senegal's mining sector. After recruiting private investments and receiving a loan from a state agency, Eeximcor built a processing mill at Sabodala. The DMG authorized the company to exploit oxidized portions of the deposit (estimated at $1 / 8$ of the deposit), while they continued to search for partners to mine the remaining deposit. Eeximcor began mining operations in June 1997. Within a year, the administration ordered the closure of Eeximcor on the grounds that Eeximcor had violated the terms of its exploitation permit.

The timing of Eeximcor's closure was propitious for the Senegalese state and the DMG's growing ambitions for Senegal's gold reserves.' By the close of the 1990s, the price of gold was rising and the neighboring states of Mali and Guinea had already emerged as major new African gold producers. By 1997, Senegal had issued 28 exploration permits for gold to a total of 24 companies, several of which were major players in the Anglophone gold industry (Le Soleil 1997). The Sabodala project stalled during the Senegalese presidential elections of 2000 when Abdoulaye Wade became Senegal's third president. Wade ran on an agenda promoting direct foreign investment and privatization, a decisive break from the nationalist economic policies pursued over 40 years of combined rule by Senegal's socialist party. Early in his candidacy, Wade emphasized mining as a key pillar for economic growth in Senegal. He kept his promise: shortly after entering office, Wade called for "international partners" to develop Senegal's mining potential, with a focus on Kédougou's gold reserves (Le Soleil 2005). In 2003, under World Bank guidance, Wade adopted a pro-market mining code that gave foreign investors considerable tax breaks on duties, sales taxes, and imports (République du Sénégal 2003).

The 2003 Mining Code, combined with rising gold prices, attracted dozens of exploration firms to Kédougou. At the time, companies based in historic gold mining countries-Canada, the United States, Australia, and South Africa-began to branch out into greenfield territories in West and East Africa, Southeast Asia, and in South America as more accessible deposits became

- Critics accused the state of intentionally sabotaging the Senegalese company, Eeximcor, in order to market the Sabodala deposit for exploitation by a capital-rich foreign partner (Coulibaly 2003). 
depleted or too costly to mine in their countries of origin (on these developments on a global scale, see Kirsch 2014). Many of these firms were "juniors," focused on exploration and funded by venture capital that converted their discoveries into mid-tier production companies or sold the results of their research to "senior" production companies. Technological changes in the mining industry also made West Africa more attractive to foreign investors. The growth in open-pit mining replaced laboring men with bulldozers. New chemical processing techniques recuperated more gold per ounce from lower-grade ores, considered unprofitable to mine in the past.

In 2004, the Minister of Mines re-opened the Sabodala project to private bidding. A year later, an Australian junior, Mineral Deposits Limited (MDL) — which included some of the same high-level personnel as Paget mining-signed a mining convention with the Senegalese state for a $20 \mathrm{~km}^{2}$ permit for Sabodala. MDL undertook further exploration drilling in June 2005, and MDL's exploration permit was converted to a mining concession in 2007. MDL upgraded its exploration camp and built a gold mining mill and, in 2009, the company poured its first gold bar. A year later, MDL sold its shares to Teranga Gold Corporation, a Canadian company created to acquire MDL. In 2014, Teranga also completed the acquisition of permits and research data held by the Canadian-based Oromin Venture Group, whose permits bordered the Sabodala mining concession and encompassed the villages of Mamakhono, Bransan, Dendifa, Mankana, Bambaraya, and Maki Medina and several historic diouras of Bélédougou. In subsequent years, Teranga acquired additional exploration permits in the Kédougou region, bringing its "Regional Land Package" to over 1000km² (on Teranga's land acquisitions, see Ling et al. 2017).

The shifting permitting rights for Sabodala makes for tedious storytelling, but it reveals the compromises African states made in marketing shelf projects to private investors in the context of economic austerity and pressure from international lending agencies. It also evidences the deeper and multiple histories of discovery and labor attached to the Sabodala deposit.

\section{The Political Life of Gold Exploration}

There was no single moment in which the Sabodala deposit was discovered. Oral histories and geological reports make this clear. Residents of Bélédougou were the first to discover and mine the alluvial gold associated with the deposit. But they lacked knowledge of the depth of the undergirding lode-ore reserve and larger geological context as determined by later generations of geologists working with airborne geophysical data, outcrop mapping, trenching, surface geochemistry, diamond drilling, and structural computer models. Moreover, using the locally forged iron hand-tools available to orpailleurs during the greater part of the twentieth century, local populations would have been incapable of mining Sabodala to the depth reached by the open-pit shoveling technologies currently in use by Teranga Gold or even those of Eeximcor in the 1990s. Descendants of orpailleur families do not deny these divergences in technological capacity and knowledge of the underground. Rather, they insist that national and expatriate geologists would never have explored Sabodala if not for the discoveries made by orpailleurs. Few geologists deny this claim. The question up for debate is when the messy compendium of silts, quartz-carbonate, albite-pyrite veins, and alluvial mineralization that once comprised Sabodala 
became a gold deposit, valued exclusively for its potential to produce gold? Was Sabodala discovered when women from Bélédougou scooped alluvial silts into gourds on the banks of a stream that wove through the rocky crevices of the mountain? Or when men from Bélédougou dug shafts into the earth, ranging from five to thirty meters underground? Or when French and Soviet geologists dug exploration trenches into the earth and tested soil samples? Or is Sabodala rediscovered each time a different set of human hands or computer techniques touches or models this complex geophysical body?

If these are ontological questions (Richardson and Weszkalnys 2014; Ferry and Limbert 2008), they are also legal problems. For one, Senegalese mining law does not recognize the gold discoveries of local citizens-at least not explicitly. The four mining codes ratified by Senegal's parliament since independence $(1964,1988,2013,2016)$ declare the subsoil the sovereign and exclusive property of the Senegalese state. These codes established that only a state-sanctioned mineral research permit can give priority to the permit holder to an exploitation permit covering the same territory. In addition, permit holders must demonstrate adequate capital and technical requirements to carry out mining activities, which has long placed access to mining permits beyond the means of most of Kédougou's rural residents. According to the current law, the fact that exploration firms might have selected a given permit due to the presence of artisanal mine workings is extraneous: firms are not required to pay indemnities to orpailleurs.

Since 2003, Mining Codes elaborated by Senegal's Ministry of Mines and Energy include mechanisms for rural residents of gold-producing zones to access formal mining rights (République du Sénégal 2003, 2016). In 2013, the Ministry of Mines issued an order stipulating that Senegalese citizens bearing a state-issued card can prospect and dig for gold within "corridors" (couloirs) designated by the state exclusively for orpaillage (République du Sénégal 2013). The first corridors were drawn in 2014 after a visit to the region by Macky Sall, Senegal's current president. At Sall's order, the Senegalese army bulldozed diouras slated for near-term extraction by Teranga Gold and the Australia-based firm, Bassari Resources. Other dioura siteslocated on land deemed of little interest for industrial-scale mine development-were left untouched. Moreover, some of the GPS coordinates of the "corridors" established by the Ministry of Mines were located on pre-existing diouras, effectively legalizing these deposits. Other "corridors" were drawn on land that had never been mined by local populations. As this article goes to press, orpailleurs in Kédougou are pressuring the state to expand the corridors, claiming that they have depleted gold within the corridors designated by the state in 2013 (Thiam 2018).

Senegal's most recent mining code, ratified by parliament in 2016, creates several additional mechanisms for rural residents to acquire formal mining rights. These include a permit for (1) "semi-mechanized mining" (exploitation semi-mécanisée), which accords exclusive mining rights for the permitted substance up to 15 meters on a perimeter of 50 hectares or less, and (2) an authorization for "artisanal mining" (exploitation minière artisanale), defined as any activity consisting of extracting minerals with the use of "manual and traditional methods and procedures" (République du Sénégal 2016). It is notable, however, that neither of these exploitation permits confer exclusive mineral exploration rights to the permit-holders. In fact, semi-mechanized and artisanal mining permits can be accorded within the perimeters of 
exploration permits given to highly capitalized exploration firms. The state also reserves the legal right to retract these permits in the event of the confirmation of a "more important" deposit within the perimeter of the permit. In sum, even if rural residents acquire a "semi-mechanized" or "artisanal" gold mining permit, they can lose this authorization if an exploration company documents a deposit of "industrial-scale" interest within the same zone.

The very definition of what comprises a mineral "deposit" or "reserve" of economic interest is also historically contingent. The constitution of a mineral reserve is defined by the classification schemes of the countries in which exploration and mining firms list their stock; such as Canada, Australia, and South Africa. Resource definition requirements, which were tightened after the "Bre-X" scandal of the mid 1990s-in which a junior exploration company made false claims to massive gold discoveries in Indonesia (see Tsing 2000)—are designed to protect investors. Although the schemes differ, in general, they define mineral "reserves" as those deposits known to exist with a relative degree of certainty based on geological studies, and that are economically exploitable with available technologies. By contrast, mineral resources (which include mineral reserves) refers to the total amount of a given material, regardless of the cost of mining it.. Thus, the very definition of a mineral reserve is shaped by shifting market prices for gold, available infrastructure, and the legal jurisdictions of Senegal and the countries in which companies list their stock. Of course, changing mining technologies also shape the economic viability of mining a given deposit. Consider that earlier generations of geologists who worked for BRGM, Sénégalo-Sovietique, and the UNO estimated the Sabodala deposit at 3 tons and then 17 tons. Today, the Sabodala mine produces over 200,000 ounces of gold per year, and the life of the mill continues to expand as geologists discover new deposits within Teranga's permits.

Just as the scope, scale, and market value of Sabodala has shifted across the decades, the geography of Sabodala has also changed dramatically since industrial-scale mining of the deposit began in 2009. The "Sabodala Mining License" has grown from the initial $20.3 \mathrm{~km}^{2}$ mining permit acquired by Teranga from MDL to include the permits of Oromin and the non-contiguous Gora Project. Today, Teranga holds $290.2 \mathrm{~km}^{2}$ in exploitation permits in addition to close to $1000 \mathrm{~km}^{2}$ in exploration permits (figures taken from Ling et al., 2017:4-1). Combined, these properties constitute Teranga's "Land Package." Teranga has halted exploitation of the Sabodala deposit itself, with plans to reopen mining in the future. Currently, the company is mining several other deposits within their expansive permits; including Gora, Golouma South, Golouma West, and Kerekounda. Most of these documented deposits can be mined with open-pit techniques, with some underground mining projected to begin in 2022 (Ling et al., 2017:1-11-12).The life of the Sabodala mining project is estimated to end in 2031, but could be extended with the discovery of more deposits within its exploration permits in southeastern Senegal. Other deposits in the "pipeline" for exploitation include Goumbati West, Maki Medina, and Niakafiri. Kerekounda, Golouma, and Niakafiri were formerly diouras mined by the population of Bélédougou.

10 The classification schemes commonly used by companies operating in Senegal include: Canadian Institute of Mining, Metallurgy, and Petroleum Classification; the Australian Joint Ore Reserves Committee Code; and the South African Code for the Reporting of Mineral Resources and Mineral Reserves. 
Fresh discoveries on Teranga's $1000 \mathrm{~km}^{2}$ Land Package present a range of possible outcomes for the Senegalese villages located within its permits. Expansions to the Sabodala project could translate into more formal employment for local residents, who are prioritized for jobs in the mines. It could also increase funds earmarked for local development projects, which Teranga contributes to on a voluntary basis and at a rate fixed by the Senegalese state per ounce of refined gold (Ling et al. 2017:6-4). At the same time, residents in villages situated on or nearby gold deposits are at risk of displacement if the state deems exploitation of the deposit in the interest of the "public good." (République du Sénégal 2016, esp. Titre V). This was the case for several villages relocated prior to the opening of the MDL-operated mine. The resettlement of these villages remains controversial, particularly as they face shortages in water and residents complain of the poverty of the land for agriculture and pasturage compared to the land they inhabited before the removal of their village (Amnesty International 2014). Teranga has already announced its intention to exploit the Niakafiri deposit, which will necessitate moving the village of Sabodala itself (Ling et al. 2017:1-5). One guaranteed outcome of new discoveries is that local residents will be prohibited from mining historic diouras slated to become open-pit gold mines.

During the construction of the Sabodala mine by MDL in 2007-2008, journalistic, activist, and scholarly coverage of gold mining in Kédougou focused on how local residents would benefit from the expansion of private mining interests in the country's poorest and most remote region. This question exploded in December 2008, when residents of Kédougou protested the insufficient employment of local residents in the Sabodala mine, then operated by MDL. Protestors also targeted the state's opaque management of funds earmarked for regional development and apparent favoritism of non-local Senegalese for unskilled jobs (Diallo 2009). Senegalese armed forces violently repressed the protest, leading to the death of a young man. Over twenty men and women, most under the age of 25 , were jailed. They were released by presidential pardon, a gesture evaluated by many locals as a political appeasement to Kédougou just in advance of the next round of regional and presidential elections. Several years later, the problem animating protests in Kédougou centers on the loss of diouras to corporate mining interests. This was epitomized by the controversy surrounding the conversion of the Gora deposit, formerly the primary dioura of the village of Diakhaling, into a "satellite" open-pit mine to feed the Sabodala mill. Located roughly $28 \mathrm{~km}$ northeast of the Sabodala processing plant, Gora had grown to host thousands of orpailleurs from Mali and Guinea by 2010. Teranga Gold received state approval to mine Gora in 2015. In prior years, local authorities made several attempts to evacuate orpailleurs from Gora, which were aborted after orpailleurs attacked security vehicles and a group of elderly women protested against armed forces. It was not until 2014, at the order of the President Macky Sall, that the army forcibly bulldozed the dioura of Gora." During this time period, representatives of Diakhaling and surrounding villages boycotted meetings organized to validate the terms of an "Environmental and Social Impact Assessment" (ESIA) of the Gora Project-the only moment in which local populations and regional representatives are formally consulted in the approval of mining projects. Residents of Diakhaling pointed to the approval of

"Author's Interviews, March-April 2014. 
the ESIA by regional authorities as evidence of the widespread corruption and collusion of political authorities with corporate mining interests. They argued that benefits from mining the dioura of Gora were far greater than those redistributed by Teranga Gold, and that they retained a right to mine Gora on the grounds that they had been the first to discover the deposit."

Despite the ultimate loss of Gora, orpailleurs constitute a political constituency the Senegalese state and mining companies cannot afford to ignore or to dispossess entirely from regional gold deposits. Orpailleurs in Kédougou have proven capable of mounting destructive protests against state policies toward the region's mining sector: burning government property, blocking roads, and threatening the safety of corporate personnel (d'Avignon 2016, chap. 7). Any visit to the Sabodala Mine by the Ministry of Mines is followed by a visit to leaders of the region's prominent diouras. The Ministry of Mines' orpaillage regulations of 2013, and the expanded opportunities for local exploitation permits incorporated into the Mining Code of 2016, is further evidence of the state's recognition of the rights of rural residents to the sub-surface. Negotiations over access to other diouras located within Teranga's permits are ongoing (see Thiam 2018).

\section{Conclusion}

When the Senegalese state re-opened the Sabodala shelf project for private bidding in 2004, the Direction of Mines advertised Kédougou as an emergent gold mining district similar to Kayes, a region located just over the border in western Mali (Diallo 2009). These projections are proving true. Kédougou's gold industry is rapidly recovering from a slow-down due to falling gold prices in recent years. The Sabodala mine is expanding and two new open-pit mines are scheduled to open within the year. However, mining the natural wealth of the Kédougou-Kenieba Inlierhome to one of the world's oldest contiguous indigenous gold mining traditions-also unearths earlier histories of discovery and expectations tied to the decades of labor, expertise, and capital invested in discovering gold deposits. One branch of the history of gold exploration in Kédougou-to which this article only gestures-is rooted in the inter-generational transmission of mining and prospecting techniques among Manding speaking clans and villages who have mined dry-season diouras for centuries. Another branch grows from the state's efforts, beginning in the 1960s, to recruit expertise from abroad to model the subsurface of southeastern Senegal.

As the case of Sabodala makes clear, the production of subterranean knowledge in Africa is profoundly multi-vocal and, therefore, contested. Local residents discovered Sabodala's alluvial deposits. But geologists working for the USSR, BRGM, UNO, Eeximcor, Paget, MDL, Oromin, and Teranga Gold deepened knowledge of the parent-rock deposit and its value to the state, to shareholders, and to the villages dotting the interior of Teranga's permits. Similar stories can be told about the discovery of gold deposits in Mali and Guinea that are currently mined by companies listed on the stock exchange of NASDAQ, Toronto, or London. A striking example is an open-pit oxide gold mine operated by Anglo-Gold Ashanti-one of the continent's largest gold producers-in the village of Kentinian in the region of Siguiri, Guinea. French geologists

${ }_{12}$ Ibid. 
working for the colonial state initially documented Kentinian in the 1930s, but they were guided to this "discovery" while tracking the activities of orpailleurs. Similar to Teranga Gold in Senegal, Anglo-Gold Ashanti has modeled, mapped, and mined gold at depths to which orpaillage techniques could never reach. Yet the original "discovery" of this auriferous zone was guided by the activities of local miners and smelters of iron and gold. While these earlier discoveries are not protected or recognized by the mining laws of Senegal nor Guinea, orpailleurs draw on their contribution to discovering these deposits in mobilizing protests, lobbies, and negotiations with the state and private mining companies. The question of who should benefit from the extraction of deposits like Sabodala, Gora, and Kentinian is debated and defined through various registers: modifications to state mining codes, reports and campaigns of international human rights and environmental groups, and citizen-led protests against the state in these mineral zones.

Anthropologist Gisa Weszkalyns (2015:631) describes the "pauses" characteristic of petroleum research in Sao Tome and Principe, "frontier regions," she qualifies, "where scientific knowledge is incomplete, and geological conditions challenging." In a similar vein, the pauses between the discovery of Sabodala by orpailleurs, by the mineral missions of the 1960s-70s, and the revitalized exploration of the Sabodala "shelf project" in the 2000s, testify to the contradictory temporal processes entailed in the capitalist accumulation of nature in the context of shifting

global market prices, the evolution of mining technologies, and the geographic reorientation of gold mining from the Global North to the Global South. As the view from Mamakhono reveals, however, these pauses also structure memory, anticipation, and grievances produced in the intimate encounters among rural residents, geologists, and prospectors. This article opens up the sociological history of these pauses to further analysis by historians and ethnographers of subterranean knowledge production and the ambiguous legal, epistemological, and ontological status of hard metal "discoveries" in colonial and post-colonial Africa.

\section{Acknowledgments}

This article is based on research funded by the Wenner Gren Foundation, the Social Science Research Council, the National Science Foundation, and the University of Michigan. I am grateful to Gabrielle Hecht and Stuart Kirsch and to the editorial staff of Engaging Science, Technology, and Society. I thank Jessica Rolston Smith, Roopali Phadke, and Abby Kinchy for the invitation to write this article and to participate in the NSF-funded workshop on STS Underground, hosted by the Colorado School of Mines. My deepest gratitude is to Falaye Danfakha, Linda d'Avignon, Pape Diallo, Adji Seck, El Hadji Cisse, and to many other friends and colleagues in Kedougou.

\section{Author Biography}

Robyn d'Avignon is an Assistant Professor of History at New York University. An anthropologist and historian of West Africa, her research examines the deeper historical trajectories of the postcolonial state, natural resource use, and technological practice in Senegal, Guinea, and Mali. 


\section{References}

Amnesty International. 2014. "Mining and Human Rights in Senegal: Closing the Gaps in $\begin{array}{llllll}\text { Protection." May 5. Accessed } & \text { September 19, }\end{array}$ https://www.amnesty.ca/sites/amnesty/files/p4350_senegal_mining_report__web_en.pdf.

Appel, H. 2012. "Offshore Work: Oil, Modularity, and the How of Capitalism in Equatorial Guinea." American Ethnologist 39:692-709. $\quad$ http://dx.doi.org/10.1111/j.15481425.2012.01389.x.

Ballard, C., and G. Banks. 2003. "Resource Wars: The Anthropology of Mining." Annual Review of Anthropology 32:287-313. https:/ / doi.org/10.1146/annurev.anthro.32.061002.093116.

Bassot, J.P. 1961. Etude Géologique du Sénégal Oriental et de ses Confins Guinéo Maliens. Orleans: Mémoires du Bureau de Recherche Géologique et Minière, no. 40.

Bridge, G. 2009. "Material Worlds: Natural Resources, Resource Geography and the Material Economy." Geography Compass 3(3):1217-1244. http://dx.doi.org/10.1111/j.17498198.2009.00233.x.

Braun, B. 2000. "Producing Vertical Territory: Geology and Governmentality in Late Victorian Canada." Cultural Geographies 7(7):7-46. https: / / doi.org/10.1177/096746080000700102.

CNBC Africa. 2015. “The positive impact of Teranga Gold's Sabodala Mine in Senegal." Accessed on Oct 1, 2017. https:// www.youtube.com/ watch?v=aouwo7jAC-0.

Coulibaly, A. L. 2003. “La Nébuleuse autour du Sabodala.” La Gazette.

Curtin, P. 1973. “The Lure of Bambuk Gold." Journal of African History 14(4):623-631.

Crush, J., A. Jeeves and D. Yudelman. 1991. South Africa's Labor Empire: A History of Black Migrancy to the Gold Mines. Boulder, CO: Westview Press.

d'Avignon, R. 2016. "Subterranean Histories: Making 'Artisanal' Miners in French West Africa." Ph.D. diss, University of Michigan.

Dumett, R. R. 1998. El Dorado in West Africa: The Gold-Mining Frontier, African Labor, and Colonial Capitalism in the Gold Coast, 1875-1900. Athens, OH: University of Ohio Press.

Dixey, F. 1961. The Investigation of Geology and Mineral Resources in Africa. Paris: UNESCO.

Diallo, M.L. 2009. "Mine d'Or et Développement Durable: Quelques Réflexions sur le Site de Sabodala (Sénégal Oriental)." EchoGeo 8. Accessed 19 Sep 2017. http:/ / journals.openedition.org/echogeo/11103.

__ 2006. "Mines et dynamiques spatiales dans le Sénégal oriental, l'exemple de la communauté rural de Khossanto." Masters thesis, Université de Gaston Berger, Senegal.

Ferry, E. and M.E. Limbert. 2008 “Introduction." In Timely Assets: The Politics of Resources and Their Temporalities, edited by E. Ferry and M.E. Limbert, 3-24. Santa Fe: School for Advanced Research Press.

Ferguson, J. 1999. Expectations of Modernity: Myths and Meanings of Urban Life on the Zambian Copperbelt. Berkeley: University of California Press. 
2006. Global Shadows: Africa in the Neoliberal World Order. Durham, NC: Duke University Press Books.

Freund, B. 1981. Capital and Labour in the Nigerian Tin Mines. Harlow: Longman.

Goldman, M.J. and M. D. Turner. 2010. "Introduction." In Knowing Nature: Conversations at the Intersection of Political Ecology and Science Studies, edited by M. J. Goldman, P. Nadasdy, and M. D. Turner, 1-24. Chicago: Chicago University Press.

Gluckman, M. 1961. “Anthropological Problems Arising from the African Industrial Revolution.” In Social Change in Modern Africa, edited by A. Southall. Oxford: Oxford University Press.

Gokee, C. 2016. Assembling the Village in Medieval Bambuk: An Archaeology of Interaction at Diouboye, Senegal. Sheffield, UK: Equinox Press.

Gray, C. 2002. Colonial Rule and Crisis in Equatorial Africa: Southern Gabon, c. 1850-1940. Rochester: University of Rochester Press.

Hayden, C. 2003. When Nature Goes Public: The Making and Unmaking of Bioprospecting in Mexico. Princeton: Princeton University Press.

Hilson, G. and N. Yakovleva. 2007. "Strained Relations: A Critical Analysis of the Mining Conflict in Prestea, Ghana." Political Geography 26(1):98-119. https:/ / doi.org/10.1016/j.polgeo.2006.09.001.

Jacobs, N. 2016. Birders of Africa: History of a Network. Yale: Yale University Press.

Kirsch, S. 2014. Mining Capitalism: The Relationship Between Corporations and their Critics. Berkeley: University of California Press.

. 2006. Reverse Anthropology: Indigenous Analysis of Social and Environmental Relations in New Guinea. Stanford: Stanford University Press.

Kneas, D. 2016. "Subsoil abundance and surface absence: A Junior Mining Company and its Performance of Prognosis in Northwestern Ecuador." Journal of the Royal Anthropological Institute 22 (S1):67-86. http:/ / dx.doi.org/10.1111/1467-9655.12394.

Kaup, B. 2008. “Negotiating Through Nature: The Resistant Materiality and the Materiality of Resistance in Bolivia's Natural Gas Sector." Geoforum 39: 1734-42. https:/ / doi.org/10.1016/j.geoforum.2008.04.007.

Le Soleil. 2005. "Mines, plus d'attrait pour les investisseurs," Mar 23. 1997. "La ruée vers l'est," Apr 8.

Ling, S., P. Nakai-Lajoie, P. Mann, K. A. Altman, and J. Sepp. 2017. "Technical Report on the Sabodala Project, Senegal, West Africa." Roscoe Postle Associations, Inc., Aug 13.

Luning, S. and R. J. Pijpers. 2017. "Governing Access to Gold in Ghana: In-depth Geopolitics on Mining Concessions." Africa 87(4):758-79. https:/ / doi.org/10.1017/S0001972017000353.

.2014. "The Future of Artisanal Miners from a Large-Scale Perspective: From Valued Pathfinders to Disposable Illegals." Futures (62)"67-74. https:// doi.org/10.1016/j.futures.2014.01.014.

MacKenzie, D. 2009. Material Markets: How Economic Agents are Constructed. Oxford: Oxford University Press. 
MacKenzie, D., D. Beunza, Y. Millo, and J.P. Pardo-Guerra. 2012 “Drilling Through the Allegheny Mountains: Liquidity, Materiality, and High Frequency Trading." Journal of Cultural Economy 5(3):279-96. https: / / doi.org/10.1080/17530350.2012.674963.

MacArthur, J. 2016. Cartography and the Political Imagination: Mapping Community in Colonial Kenya. Athens, Ohio: Ohio University Press.

Monika, B., D. Goodwin, and J. Mesman. 2010. "Ethnographies of Diagnostic Work: Introduction." In Ethnographies of Diagnostic Work: Dimensions of Transformative Practice, edited by M. Buscher, D. Goodwin and J. Mesman, 1-14. New York: Palgrave Macmillan.

Nash, J. 1993. We Eat the Mines and the Mines Eat Us: Dependency and Exploitation in Bolivian Tin Mines. New York: Columbia University Press.

Persaud, A. et al. 2017. "Artisanal and Small-Scale Gold Mining in Senegal: Livelihoods, Customary Authority, and Formalization." Society \& Natural Resources 30(8):980-993. https: / / doi.org/10.1080/08941920.2016.1273417.

Powerdermaker, H. 1962. Copper Town: Changing Africa: The Human Situation on the Rhodesian Copperbelt. New York: Harper \& Row.

Okoh, G.A. 2014. "Grievance and Conflict in Ghana's Gold Mining Industry: The Case of Obuasi." Futures (62):51-7.

Osseo-Asare, A. D. 2014. Bitter Roots: The Search for Healing Plants in Africa. Chicago: Chicago University Press.

Ozden-Schilling, T. "Number and Narrative: Temporalizing Trust in Rare Earth Elements Exploration." Unpublished Manuscript.

Pritchard, S. 2013. "Joining Environmental History with Science and Technology Studies: Promises, Challenges, and Contributions." In New Natures: Joining Environmental History with Science and Technology Studies, edited by D. Jorgensen, F.A. Jorgensen, and S. Pritchard, 1-20. Pittsburg: University of Pittsburgh Press.

Rajak, D. 2011. In Good Company: An Anatomy of Corporate Social Responsibility. Stanford: Stanford University Press.

Rankin, W. 2016. After the Map: Cartography, Navigation, and the Transformation of Territory in the Twentieth Century. Chicago: Chicago University Press.

République du Sénégal. 2016. Code minier du Sénégal, loi n 2016-32 du 08 novembre 2016, Dakar. . 2013. Arrête portant organisation de l'activité d'orpaillage, Ministère de l'Energie et des Mines, du 14 juin 2013, Dakar.

2003. Code minier du Sénégal, loi n 2003-36 du 24 novembre 2003, Dakar.

Richardson, T. and G. Weszkalnys. 2014. "Resource Materialities." Anthropological Quarterly 87(1):5-30. doi:10.1353/ anq.2014.0007.

Rolston, J. S. 2013. “The Politics of Pits and the Materiality of Mine Labor: Making Natural Resources in the American West." American Anthropologist, 115: 582-594. http:/ / dx.doi.org/10.1111/aman.12050.

Sawyer, S. Crude Chronicles: Indigenous Politics, Multinational Oil, and Neoliberalism in Ecuador. Durham, NC: Duke University Press, 2004. 
Schiebinger, L. 2007. Plants and Empire: Colonial Bioprospecting in the Atlantic World. Cambridge, MA: Harvard University Press.

Scott, J. 1998. Seeing Like a State: How Certain Schemes to Help the Human Condition Have Failed. New Haven: Yale University Press.

Summers, R. 1969. Ancient Mining in Rhodesia and Adjacent Areas. Salisbury: Trustees of the National Museum of Rhodesia.

Taussig, M. 1980. The Devil and Commodity Fetishism in South America. Chapel Hill: University of North Carolina Press.

Teranga Gold Corporation Website. 2018. "Senegal: Exploration in Senegal." Accessed 28 Jan 2018. http:/ / www.terangagold.com/default.aspx?SectionId=d7331c98-2834-4c0d-875211ad923fc785\&LanguageId.

Thiam, E. I.. 2018. "Kharékhéna : Les orpailleurs demandent de nouveaux couloirs." Le Soleil, 24 Jan.

Tilley, H. 2010. Africa as a Living Laboratory: Empire, Development, and the Problem of Scientific Knowledge, 1870-1950. Chicago: University of Chicago Press.

Toro Gold Mako Project, Senegal. Published Sep 29, 2015, Accessed 20 Jan 2018. https: / / www.youtube.com/watch?time_continue=7\&v=fILeNtJ6k6I.

Tsing, A. 2000. "Inside the Economy of Appearances." Public Culture 12(1):115-144. https:// doi.org/10.1215/08992363-12-1-115.

Van Onselen, C. 1976. Chibaro: African Mine Labour in Southern Rhodesia, 1900-1933. London: Pluto Press.

Walsh, A. 2012. "After the Rush: Living with Uncertainty in a Malagasy Town." Africa 82(2): 23551.

Welker, M. 2014 Enacting the Corporation: An American Mining Firm in Post-authoritarian Indonesia. Berkeley: University of California Press.

Weszkalnys, G. 2015. "Geology, Potentiality, Speculation: On the Indeterminacy of First Oil." Cultural Anthropology 30(4): 611-639. DOI: https:/ / doi.org/10.14506/ca30.4.08.

Westermann, A. 2015. "Geology and World Politics: Mineral Resource Appraisals as Tools of Geopolitical Calculation, 1919-1939." Historical Social Research 40(2):151-173. https:// doi.org/10.12759/hsr.40.2015.2.151-173.

Wilks, I. 1971. "The Mossi and Akan States, 1500-1800." In History of Africa, Vol. 1, edited by J.F.A. Adjaye and M. Crowder, 344-86. London: Longman.

Winichakul, T. 1994. Mapping Siam: A History of the Geo-Body of A Nation. Honolulu: University of Hawaii Press.

Wood, D. and J. Fels. 2008. The Natures of Maps: Cartographic Constructions of the Natural World. Chicago: Chicago University Press. 